\title{
PENDIDIKAN ANAK USIA DINI PERSFEKTIF ISLAM DAN BARAT (Studi Pustaka Tentang Teori PAUD)
}

\author{
Rosita*1, Ahmad Buchori Muslim*2 \\ STIT Islamic Village Tangerang, Indonesia \\ 1'rositajkt1981@gmail.com, ${ }^{2}$ ahmadbuchori23@gmail.com
}

\begin{abstract}
This library research was conducted with a background of enriching discourse and paradigm regarding the pattern of Early Childhood Education (PAUD) in Islamic and Western perspectives. In addition, researchers want to detect and see the pioneer of PAUD theory. Because there are some similarities from the originators of western theory with the Islamic PAUD theory. Although there are different things between the two perspectives. One of them, the western perspective reveals the beginning of the right AUD education since the womb, but vice versa with AUD education in the Islamic perspective, that is, starting from choosing a partner. So that the idea of this research arises by using a literature analysis. Thus, this research is expected to provide a new positive discourse and have a purpose to provide an actual understanding of what is happening around us.
\end{abstract}

Keywords: Early Childhood Education; Islamic and Western perspectives

\begin{abstract}
Abstrak
Penelitian pustaka ini dilakukan dengan latar belakang memperkaya wacana dan paradigma mengenai pola Pendidikan Anak Usia Dini (PAUD) dalam persfektif Islam dan Barat. Selain itu peneliti ingin mendeteksi dan melihat pelopor dari teori PAUD. Karena terdapat beberapa kesamaan dari para pencetus teori barat dengan teori PAUD Islam. Meskipun ada hal yang berbeda antara kedua persfektif tersebut. Salah satunya, persfektif barat mengungkapkan awal mula pendidikan AUD yang tepat semenjak dalam kandungan, tapi sebaliknya dengan pendidikan AUD dalam persfektif Islam, yaitu dimulai sejak memilih pasangan (jodoh). Sehingga ide penelitian ini muncul dengan

E-mail address: ${ }^{1}$ rositajkt1981@gmail.com, ${ }^{2}$ ahmadbuchori23@gmail.com
Peer reviewed under reponsibility of STAI Ma'had Aly Al-Hikam Malang
C2019 STAI Ma'had Aly Al-Hikam Malang, All right reserved, This is an open access article under
\end{abstract}


DOI: $10.32478 /$ al-mudarris.v\%vi\%i.264

menggunakan analisis studi pustaka. Dengan demikian penelitian ini diharapkan dapat memberikan wacana baru yang positif dan memiliki tujuan untuk memberikan pemahaman sebenarnya yang terjadi di sekitar kita.

Kata kunci: Pendidikan Anak Usia Dini; Perspektif Islam dan Barat

\section{A. PENDAhULUAN}

Pendidikan anak usia Dini dalam beberapa dasawarsa ini menjadi perbincangan yang hangat. Teori-teorinya pun dikaji demi meningkatkan perkembangan yang maksimal bagi Anak Usia Dini. Baik dari perkembangan ketika janin dalam perut ibunya, teori otaknya sampai perkembangan ketika bayi lahir hingga mencapai baligh.

Namun pada hakikatnya, perkembangan anak ternyata memiliki sejarah yang panjang, dengan dinamika perbedaan persepsi, sudut pandang dan munkin paradigma yang berbeda-beda. Ini terbukti bahwa selama berabad-abad yang lalu, manusia melihat bayi atau anak-anak sebagai makhluk yang telah terbentuk secara utuh, sebuah miniatur orang dewasa. Aries (1960) dalam Crain melukiskan betapa pandangan ini amat mendominasi seluruh abad pertengahan. Lukisan-lukisan abad pertengahan contohnya selalu menggambarkan anak-anak bahkan yang baru lahir dengan proporsi tubuh dan cirri-ciri wajah manusia dewasa. Anak-anak berbeda hanya dalam ukuran, seolah mereka sudah dibentuk sebelumnya (Preformed) dalam cetakan orang dewasa. ${ }^{1}$

Secara sosial, anak-anak abad pertengahan juga diperlakukan layaknya orang dewasa. Pada umur 6 atau 7 tahun mereka sudah boleh memasuki kumpulan orang dewasa seperti bekerja, bergaul dan bermain dengan orang dewasa. ${ }^{2}$

Tapi menurut Ausubel (1958) dalam Crain, Performasionanisme juga berkaitan dengan egosentrisme alamiah orang dewasa. Orang dewasa cenderung beranggapan kalau semua hidup manusia memiliki bentuk dan fungsi yang sama dengan yang mereka miliki. Butuh kelapangan pikir khusus untuk melihat sifat-sifat unik kehidupan di dalam periode yang berbeda-beda, dan kelapangan pikir ini tidak mudah dicapai.

${ }^{1}$ Crain, William, Penerj. Yudi Santoso Teori Perkembangan Konsep dan Aplikasi, Penerbit Pustaka Pelajar, Yogyakarta ; 2007.h.33-34

${ }^{2}$ Ibid 
Di dalam Sains, Performasionanisme sangat menyolok di teoriteori awal embriologi. Selama berabad-abad, banyak ilmuwan percaya bahwa sosok manusia kecil yang sudah terbentuk sempurna, disebut homunculus, dicangkokan di dalam sperma atau sel telur saat bersatu.

Needham (1959) dan Balinsky (1981) Mereka percaya bahwa manusia 'sudah dibentuk' dalam penciptaan instant dan baru bisa tumbuh dengan ukuran dan proporsi yang benar sampai dilahirkan. Pemikiran ini terus dipegang selama berabad-abad, dari abad ke- 5 SM hingga abad ke 18 masih banyak ilmuwan yang memegang pandangan Performasionanisme. Karena mereka mengakui kalau tidak ada bukti bagi keberadaan homunculus yang sudah terbentuk, namun mereka berkilah kalau ini disebabkan ukurannya terlalu transparan dan kecil untuk bisa dilihat. Dan ini terus bergulir hingga akhir abad 16, lalu kemudian muncul teori-teori tentang perkembangan anak yang menyoroti sosok AUD sebagai sosok yang tanpa dosa seperti kertas putih, sejak dalam kandungan hingga terlahir ke dunia.

Pandangan- pandangan yang bergulir dan tersebut di atas merupakan pandangan dari para pencetus teori barat, lain halnya dengan teori PAUD Islam, dalam Islam tolak ukur berawal dari Al-Qur'an, hadits/sunnah rasulullah dan atsar ashabi (perkataan shabat). Dan proses perkembangan anak dalam janin perempuan pun sangat jelas diterangkan dalam Al-Qur'an :

"Dan sungguh, kami telah menciptakan manusia dari saripati (berasal) dari tanah. Kemudian kami menjadikannya air mani (yang disimpan) dalam tempat yang kokoh (rahim). Kemudian, air mani itu kami jadikan segumpal daging, dan segumpal daging itu Kami jadikan tulang belulang, kemudian tulang belulang itu kami bungkus dengan daging. Kemudian, kami menjadikannya makhluk yang (berbentuk) lain. Maha suci Allah, Pencipta yang paling baik." (Q.S Al-Mukminuun, 23:12-14)

"Yang memperindah segala sesuatu yang Dia ciptakan dan yang memulai penciptaan manusia dari tanah. Kemudian, Dia menjadikan keturunannya dari saripati air yang hina (air mani) (Q.S. Sajdah, 32: 7-8) 
AL-MUDARRIS:journal of education, Vol. 2. No. 2 Oktober 2019, ISSN: 2620-5831 (print), ISSN: 2620-4355(online)

DOI: $10.32478 /$ al-mudarris.v\%vi\%i.264

Dengan demikian dalam teori-teori AUD memiliki perkembangan yang dinamis, baik dalam versi Islam ataupun barat. Namun menjadi suatu fithrah dalam teori berpikir untuk menelaah lebih jauh dan menganalisa ontologi dari hakikat teori PAUD, dari sejarah dan pioneer dalam pencetusan teori perkembangan anak serta kesinambungan dari kedua teori tersebut. Hal inilah yang menggugah pemikiran peneliti untuk menguak konsep pendidikan anak usia dini dalam persfektif Islam dan Barat.

\section{B. TINJAUAN PUSTAKA}

\section{Pendidikan Anak Usia Dini Dalam Persfektif Barat}

Ketika sebelum periode abad ke-18, seorang anak dilihat sebagai miniatur orang dewasa (perfomansionisme), tanpa membutuhkan stimulasi dan sebagainya. Namun pada paruh terakhir abad ke-18, saat penelitian mikrospis memperlihatkan bahwa embrio berkembang lewat serangkaian tahapan pandangan tersebut mulai berubah. Di dalam Sosio Eropa Performasionanisme sudah surut lebih awal sekitar abad ke-16, ketika para pemuka agama dan kaum moralis mulai menekankan kualitas-kualitas istimewa anak-anak. Menurut Aries, (1960) beberapa dari mereka (baca; pemuka agama) mengunkapkan anak-anak masuk ke dunia dengan kemurnian dan kesucian yang diberikan Tuhan namun kemudian terkorupsi.

Sementara yang lain menganggap bahwa anak-anak sudah mengusung dosa asal manusia pertama. Anak-anak, menurut mereka adalah makhluk yang tidak tahu apa-apa, yang hanya memiliki keasusialaan dan amoralitas. . Kemudian ghirah ini memunculkan beberapa teori yang mengungkapkan ontology anak usia dini dan aspekaspek yang mempengaruhi perkembangannya.

\section{a. Filsafat Pendidikan Jhon Locke (1632-1704)}

Jhon Locke dalam perkembangan anak usia dini merupakan bapak Naturalis, yang dalam perspektifnya menyarankan kepada orang tua agar memberikan peluang yang cukup bagi anak-anak untuk banyak melakukan latihan fisik, sehingga tubuh mereka menjadi kuat, bahkan Locke menyarankan agar anak-anak bermain di luar rumah apa pun musimnya sehingga mereka bisa belajar untuk bertahan dari kerasnya berbagai macam cuaca. Dalam teorinya mengenai pendidikan pada anak usia dini Jhon Locke menguraikan menjadi beberapa tindakan, yaitu : 
Penghargaan dan penghukuman yang terbaik; Masalah kedisiplinan dan aturan Locke mengungkapkan jika anak-anak butuh didisiplinkan maka harus tegas dari awal karena kebiasaan awal akan sulit diubah. Dan dari setiap perilaku sepatutnya memiliki penghargaan (reward). Penghargaan terbaik adalah pujian dan sanjungan, dan penghukuman yang terburuk adalah ketidaksetujuan. Ketika anak-anak bertindak dengan baik, kita mesti memuji mereka, membuat mereka merasa bangga; sebaliknya, waktu mereka bertindak buruk kita hanya boleh memberinya tatapan dingin, membuat mereka merasa malu. Anak-anak sangat sensitive terhadap persetujuan dan ketidaksetujuan.

Aturan-aturan; Anak belajar dari model yang kita berikan dan Memberikan model dan mempraktekkan bersama perilaku yang baik.

Karakteristik istimewa anak-anak; Anak-anak memiliki tempramen yang unik sesuai usianya, seperti suka membuat gaduh, bermain ugal-ugalan dan penuh keriangan, sehingga siasia saja kita berusaha mengubah cirri-ciri alamiah mereka. Dan menurut Locke anak terlahir seperti kertas kosong (tabularasa). Oleh karena itu dari semua penjabaran teori Locke "bahwa pendidikan pada hakikatnya merupakan proses sosialisasi”.

\section{b. Filsafat Pendidikan Rousseau (1712-1778)}

Dalam perspektif Rousseau sebagai bapak developmentalism dalam perkembangan anak usia dini, dia mengungkapkan bahwa anak-anak bukan wadah kosong atau kertas kosong melainkan sudah memiliki mode perasaan dan pemikirannya sendiri. Diantaranya: Pertama, Anak tumbuh dan belajar dengan cara mereka sendiri sesuai rencana alam. Alam seperti guru yang tersembunyi yang mendorong anak mengembangkan kemampuan yang berbeda-beda. Jika seseorang ingin membantu anak dalam proses ini, ia harus mempelajari semua hal tentang tahapan perkembangan manusia. Kedua, Dalam setiap tahapan anak memiliki karakteristik yang unik. Dan Ketiga, Pendidikan yang berpusat pada anak, "Ajarlah murid-muridmu sesuai usianya. 
AL-MUDARRIS:journal of education, Vol. 2. No. 2 Oktober 2019, ISSN: 2620-5831 (print), ISSN: 2620-4355(online)

DOI: $10.32478 /$ al-mudarris.v\%vi\%i.264

Selain itu Rousseau menjelaskan teori perkembangan manusia menjadi: Tahap I (0-2 tahun) Bayi mengalami dunia langsung lewat inderannya; Tahap II (2-12 tahun) tahap dimulai ketika anak memiliki sebuah indepensi baru dengan bisa berjalan, makan, berbicara, dll; Tahap III (12-15 tahun) masa transisi kanak-kanak dan dewasa; Tahap IV masa dewasa, anak-anak menjadi makhluk yang sepenuhnya sosial hanya di tahap keempat, dimulai dari masa pubertas dan Rousseau menyatakan bahwa pubertas dimulai dari usia 15 tahun. Dititik ini seorang mulai tertarik atau sudah membutuhkan orang lain.

\section{c. Teori Pendewasaan Arnold Gessel (1880-1961)}

Konsep kematangan menurut Gessel dalam perkembangan anak adalah produk dari lingkungannya yang berasal dari dalam yaitu aksi dari gen-gen tubuhnya, Gessel menyebutnya ini sebagai proses kematangan. Pertama, dari pertumbuhan embrio yang diawali dengan berkembangnya fungsi jantung kemudian dilanjutkan sistem syaraf utama yaitu otak dan saraf tulang belakang setelah itu baru anggota tubuh yang lain.

Kedua, perkembangan pasca lahir, yaitu proses bayi belajar mengendalikan bibir dan lidah mereka, kemudian pergerakan mata, diikuti oleh pengendalian leher, bahu lengan, telapak tangan, jari-jari, badan, tungkai dan telapak kaki mereka. Di dalam perkembangan pra-lahir dan pasca-lahir terdapat kecenderungan perkembangan perkembangan dari kepalamenuju kaki (chepalocaudal). Prinsip-prinsip Perkembangan lainnya, yaitu meliputi: Jalinan Timbal Balik; Manusia dibangun atas dasar jalinan yang bersifat bilateral, seperti dua belahan otak, dua mata, dua tangan, dua kaki, dst.; Asimetri-Fungsional, proses menyeimbangkan dualitas sifat kita (bagian dari proses penyeimbangan jalinan timbal balik); dan Pengaturan diri,

Selain itu pola pengasuhan anak menurut Gessel bahwa pertama Orang tua tidak semestinya memaksa anak memasuki pola-pola tindakan yang tidak mereka pahami, melainkan mengikuti petunjuk dari anak-anak itu sendiri. Kedua Bayi boleh diberi makan apabila telah mengindikasikasikan kesiapan. Ketiga Tahun pertama adalah waktu terbaik untuk belajar menghormati individualitas anak. Kini Gessel dikenal sebagai bapak psikologi 
anak yang mengkategorikan 10 perilaku khas anak, yaitu : Gradient of Growth (gradien perkembangan).

\section{d. Filsafat Pendidikan Montessory (1870 -1952)}

Maria Montessory seseorang yang mendedikasikan seluruh hidupnya untuk mengajar anak-anak dengan sungguh-sungguh. Lahir di provinsi Ancona tahun 1870. Berawal ketertarikannya terhadap pendidikan anak-anak yang special needs yang memberikan mereka materi dan pengajaran layaknya anak-anak normal dengan metode yang benar. Dalam teori perkembangan Montessory diperkenalkan periodisasi perkembangan anak dinataran adalah Periode kepekaan dan keteraturan, Periode kepekaan dan detail, Periode kepekaan bagi penggunaan tangan, Periode kepekaan untuk berjalan, dan Periode kepekaan terhadap bahasa.

Maria Montessori berpendapat bagian terpenting dari kehidupan bukanlah di universitas, tetapi periode pertama dari usia 0-6 tahun, karena selama periode ini seluruh instrument besar manusia terbentuk, bukan hanya kecerdasan tetapi seluruh kecakapan psikis. Anak berkembang menjadi manusia melalui tangannya dan dengan pengalamannya sendiri. Awalnya melalui bermain kemudian secara bertahap melalui kerja nyata. Tangan adalah instrumen dari kecerdasan manusia. Melalui pengalaman yang diperolehnya, ia menjadi seorang manusia, pekerjaan guru bukan untuk mengajar, melainkan untuk membantu mengembangkan "absorbent mind" atau "pikiran menyerap" anak. Penemuan fakta bahwa anak diberkati dengan pikiran menyerap telah membawa sebuah revolusi dalam pendidikan. Dan menurutnya setiap anak memiliki teori perkembangan. ${ }^{4}$

\section{Pendidikan Anak Usia Dini Dalam Persfektif Islam}

Pendidikan anak usia dini dalam Islam telah ada sejak zaman Nabi. Hal ini terlihat dari penjelasan dalam Al-Qur'an, hadits dan atsar ashabi yang berkembang saat itu. Pendidikan usia dini dalam islam terbagi menjadi 3 fase, yaitu fase memilih jodoh/pasangan, fase pranatal (dalam kandungan), dan pase pasca-natal (fase pra baligh dan

\footnotetext{
${ }^{4}$ Crain, loc.cit, h. 11
} 
AL-MUDARRIS:journal of education, Vol. 2. No. 2 Oktober 2019, ISSN: 2620-5831 (print), ISSN: 2620-4355(online)

DOI: $10.32478 /$ al-mudarris.v\%vi\%i.264

baligh). Dalam hal ini fase-fase tersebut berkaitan satu sama lain dan mepengaruhi tumbuh kembang anak.

\section{a. Fase Memilih Jodoh/Pasangan.}

Nilai-nilai dalam Islam sangat berhati-hati menentukan pilihan dalam mencari pasangan. Karena pasangan hidup dalam Islam bukanlah sekedar pendamping akan tetapi imam (bagi laki-laki) yang memandu perjalanan menuju jalan ridho-Nya, serta menjadi role model (Iaki-dan perempuan) untuk keluarganya.

Sehingga Ada 4 kriteria penentuan dalam pemilihan pasangan, sebagaimana tertuang dalam hadits nabi :

"Dari Abu Hurairah - Rhadiyallahu Anhu - dari Nabi Muhammad SAW, beliau berkata: "Seorang perempuan dinikahi karena empat perkara, karena hartanya, karena kedudukannya, karena kecantikannya, (atau) karena agamanya. Pilihlah yang beragama, maka kau akan beruntung" (Sunan alBaihaqi, no. 21333).

Hadis ini secara implisit menjadi landasan untuk menentukan cikal bakal penerus masa depan seseorang. Sebagai kualifikasi memilih pasangan baik laki-atau perempuan. Karena ketika "agama" (baca ; taqwa) baik, kemunkinan akhlak dan pergaulannya baik sehingga menentukan kebaikan keturunannya, serta terjaga muru'ahnya. Dalam ungkapan imam syafii, muru'ah meliputi empat hal yaitu berakhlak baik, dermawan, rendah hati, dan tekun beribadah."

\section{b. Fase Pra-natal (dalam Kandungan)}

Pada fase ini adalah awal stimulasi bagi tumbuh kembang janin sehingga sempurna menjadi calon bayi. Karena saat itu beberapa organ tubuh dan indera bayi mulai berfungsi seperti Pendengaran, Penglihatan dan hati (perasaan). Sebagaimana termaktub dalam Al-Qur'an bahwasanya Allah telah menciptakan penglihatan pendengaran dan hati (perasaan) sewaktu dalam perut ibu :

"Dan Allah mengeluarkan kamu dari perut ibumu dalam Keadaan tidak mengetahui sesuatu pun, dan Dia memberi kamu pendengaran, penglihatan dan hati, agar kamu bersyukur “. (QS. An-Nahl : 78). 
Dari penjelasan di atas sesungguhnya Allah telah memberikan kemampuan pada seorang bayi kemampuan untuk mendengar, melihat (meski tak jelas) dan merasakan melalui hati-akal (af'idah). Sehingga penting kiranya memberikan rangsangan/stimulasi yang tepat pada calon bayi hingga lahir ke dunia. Karena meminjam bahasa teknologi Allah telah memberikan piranti lunak (Chip) yang diinstal dalam diri manusia dan apabila diibaratkan sebagai sebuah komputer super dengan teknologi nano dan terekam di dalam lebih dari 100 milyar sel otak anak. ${ }^{5}$

Oleh karena itu akan sangat baik apabila kita sering mendengarkan dan melakukan hal-hal yang baik, seperti mendengarkan murotal Al-Qur'an, membaca Al-Qur'an serta berdialog dalam setiap kegiatan yang dilakukan dengan janin yang dikandung, melalui bahasa yang jelas (SPOK). ${ }^{6}$

\section{c. Fase Pasca-natal (Fase Pra Baligh dan Baligh)}

Fase pasca natal atau tahapan ketika seorang anak telah lahir ke dunia. Dalam Islam perkembangan setelah lahir merupakan proses perkembangan dan pendidikan sepanjang hayat (long life education), seperti ungkapan Tuntutlah ilmu dari belaian (baca; bayi) sampai liang lahat (baca; meninggal). Dan fase ini adalah fase sejuta harapan, karena setiap orang tua memiliki harapan agar anak yang lahir sehat, shalih dan cerdas atau dengan kata lain sesuai perkembangan secara biologis (usia yang sesuai dengan bertambahnya sel otak anak yang berkembang) dan kronologis (sesuai usia lahir). Keseimbangan kronologis dan biologis bisa terlihat keberhasilan perkembangannya ketika usia 40 tahun. Tahapan pendidikan yang membangun usia biologis dan kronologis anak. ${ }^{7}$ Yaitu:

Usia 0 - akil baligh ; Anak belajar "Iqro'" sehingga anak mempunyai kemampuan membaca ayat (tanda) Allah, baik yang tertulis maupun yang tidak tertulis, yang ada dalam penciptaan lengit dan bumi beserta isinya. Dengan kata lain pada usia ini

5 Yudistira dan Sisca Y. Masardi, Pendidikan Karakter Dengan Metode Sentra, Penerbit: Media Pustaka Sentra, Bekasi :2012, H. 36

6 Wismiarti, Mengapa Surga Di Telapak Kaki Ibu, Penerbit : ESQ 165, Jakarta : 2013., H. 36

7 Ibid., H. 20 
AL-MUDARRIS:journal of education, Vol. 2. No. 2 Oktober 2019, ISSN: 2620-5831 (print), ISSN: 2620-4355(online)

DOI: $10.32478 /$ al-mudarris.v\%vi\%i.264

pondasi awal seorang anak bermula untuk mencari dan proses pencarian jati diri seorang anak untuk mengarungi dan bertahan di awal kehidupannya.

Usia akil baligh -18 Tahun :Anak membaca dan mengetahui ciptaan Allah yang ada di bumi dan di langit.

Usia 18 Tahun -25 Tahun : Usia seseorang pada tahapan membaca dan memahami alasan semua ciptaan Allah bagi makhluknya (manusia, dll.)

Usia 25 Tahun - 40 Tahun : dengan pengetahuan yang dimiliki, dia mencari pengalaman hidup dan melakukan trial and error, dia pratikkan, menganalisisnya dan mengambil kesimpulan tentang segala sesuatu, tentang cara memanfaatkan semua ciptaan Allah untuk melaksanakan tugasnya sebagai khalifah.

Usia 40 Tahun- wafat : menjadi hamba yang pandai bersyukur dan siap berkarya yang menghasilkan sesuatu yang diridhai Allah. Seperti tertuang dalam Al-Qur'an :

"Kami perintahkan kepada manusia supaya berbuat baik kepada dua orang ibu bapaknya, ibunya mengandungnya dengan susah payah, dan melahirkannya dengan susah payah (pula). Mengandungnya sampai menyapihnya adalah tiga puluh bulan, sehingga apabila dia telah dewasa dan umurnya sampai empat puluh tahun ia berdoa: "Ya Tuhanku, tunjukilah aku untuk mensyukuri nikmat Engkau yang telah Engkau berikan kepadaku dan kepada ibu bapakku dan supaya aku dapat berbuat amal yang shalih yang Engkau ridhai; berilah kebaikan kepadaku dengan (memberi kebaikan) kepada anak cucuku. Sesungguhnya aku bertaubat kepada Engkau dan sesungguhnya aku termasuk orang-orang yang berserah diri." (Q.S.Al-Ahqof $: 46: 15)^{8}$

Sehingga dalam hal ini pendidikan dalam Islam merupakan ladang amal untuk bekal ketika dipanggil Sang pencipta dan di hari pertanggungjawaban. Namun, dalam tulisan ini akan menjelaskan pendidikan anak usia dini dalam Islam hingga pada usia menuju baligh, dengan mengutip ungkapan masyhur Ali bin Abi Thalib yaitu:

\footnotetext{
${ }^{8}$ https://tafsirweb.com/9581-surat-al-ahqaf-ayat-15.html
} 
"Ajaklah anak bermain dengan menyenangkan pada tujuh tahun pertama, lalu disiplinkan anak pada tujuh tahun kedua dan bersahabatlah pada usia tujuh tahun ketiga." 9

Dengan demikian, dalam Islam ada 3 tahapan dalam memberikan pola pendidikan pada anak yaitu dari usia 0 tahun -21 tahun. sebagaimana berdasarkan pola memperlakukan seorang anak menurut Ali bin Abi Thalib yaitu : ${ }^{10}$ Fase 7 Tahun Pertama (0 tahun -7 tahun); Fase 7 Tahun Kedua (8 tahun - 14 Tahun); dan Fase 7 Tahun Ketiga (15 tahun-21 tahun).

a. Fase 7 Tahun Pertama yaitu, Periode awal (0 tahun -7 tahun) merupakan cikal bakal pendidikan Anak bermula. Dalam Islam hal yang terpenting adalah pilar atau pondasi dan pondasi dalam islam adalah aqidah. Aqidah mulai dimunculkan saat bayi keluar dari perut ibundanya, dengan memperdengarkan kalimat Allah di telinga bayi, seperti Azan dan Iqomah. Sebagaimana diperintahkan Nabi Muhammad dalam sabdanya: Dari Abu Rafi', ia berkata, "Aku melihat Rasulullah SAW ażan sebagaimana ażan şalat, di telinga Husain bin Ali ketika Fathimah melahirkannya" (R. At-Tirmiżi).

Ibnu Qayyim seperti dikutip oleh Al Mun'im Ibrahim, menyebutkan bahwa rahasia azan adalah agar awal yang didengar bagi seorang yang baru dilahirkan adalah azan yang mengandung keagungan Allah SWT.

Selain itu pembacaan Azan dengan spiritual yang tinggi akan membuat koneksi di otak bayi antara azan dan perjanjiannya dengan Allah waktu bayi berusia 4 bulan dalam kandungan. saat ruh ditiupkan dan bayi mengakui bahwa Allah satu-satunya Tuhan yang wajib disembah. ${ }^{11}$ Karena hal inilah yang akan menjadi modal kecerdasan spiritual AUD. Dan usia 0-2 tahun merupakan masa emas bagi seorang anak karena semua kemampuannya mulai berkembang (kognitif, bahasa dan 2018.H.128

9 Ida. S widyawati, Anak dari surga menju surga, PT. Arga Tilanta, Jakarta

10

https://www.kompasiana.com/elokkhusna/584a2e7e8d7a61d308d3824e/mendidikanak-ala-ali-bin-abi-thalib-r-a, diunduh 11 Maret 2019

${ }^{11}$ Wismiarti, Op.cit, H. 47 
AL-MUDARRIS:journal of education, Vol. 2. No. 2 Oktober 2019, ISSN: 2620-5831 (print), ISSN: 2620-4355(online)

DOI: $10.32478 /$ al-mudarris.v\%vi\%i.264

psikomotor). Dan pada fase ini anak menyerap informasi lebih cepat dari kemampuan orang dewasa, seperti sponge yang menyerap air sehingga apapun yang diberikan kepada anak akan terserap $100 \%$. Oleh karena itu Perkembangan dan pertumbuhan AUD tidak luput dari peran orang tua, yaitu ayah dan ibu, hal ini tercermin dan sejalan dengan Hadits Abu Hurairah dan Hadiits Muslim tentang anak lahir atas dasar fitrah.

" Semua manusia dilahirkan ibunya dalam keadaan suci.(H.R.Muslim). ${ }^{12}$

"Dari (Abu) Hurairah ra. Dia berkata: Rasulullah SAW bersabda: tidak ada seorang anakpun kecuali ia dilahirkan menurut fitrah. kedua orang tuanyalah yang akan menjadikan ia yahudi, nasrani, dan majusi sebagaimana binatang melahirkan binatang dalam keadaan sempurna. Adakah kamu merasa kekurangan padanya. Kemudian abu hurairah ra. berkata: "fitrah Allah ketika manusia telah diciptakan tak ada perubahan pada fitrah Allah itu. Itulah agama yang lurus" (HR Al-Bukhari).

Dari hadits diatas dapat dijelaskan bahwa setiap bayi dilahirkan dalam keadaan suci. Bergantung kepada stimulasi orang tuanya yaitu ayah dan ibunya. Ibu sebagai sosok yang sangat dibutuhkan oleh AUD khusunya untuk usia 0-2tahun, karena saat bayi di rahim ibunya bayi merasakan seperti di surga dengan fasilitas yang serba ada dan selalu terpenuhi keinginannya. Oleh karena itu saat lahir ke dunia ibu sepatutnya selalu ada untuk bayi sebagai bagian dari stimulasi perkembangan yang berkaitan dengan sosial emosi (trustmistrust) anak yang berguna di masa yang akan datang, dengan memberikan makanan berupa ASI dan kasih sayang. Seperti yang tercantum dalam Firman Allah SWT :

"Para ibu hendaklah menyusukan anak-anaknya selama dua tahun penuh, yaitu bagi yang ingin menyempurnakan penyusuan," (QS al-Baqarah : 233). ${ }^{13}$

12 Ahmad Syawqi Ibrahim, Ensiklopedia mukjizat Ilmiyah Hadits Nabi Manusia dan Proses Penciptaannya, Sygma creative media, 2014, H.42

${ }^{13}$ https://m.republika.co.id/berita/dunia-islam/fatwa/15/06/08/nplpht-anjuranalquran-bagi-muslimah-yang-menyusui 
Kemudian usia 2-7 Tahun, Usia ini diibaratkan seperti membuat rumah di atas pondasi (pondasi yang dirangkai saat usia 0-2 tahun). ${ }^{14}$ Dalam hal prinsipil dalam melakukan pendidika pada anak usia dini terutama pada masa awal pembentukannya (rentang usia 2-7 tahun) sepatutnya mencontoh Rasulullah SAW, seperti diriwayatkan oleh Muslim bahwa Al-Sulami telah berkata,: "Maka demi bapak dan ibuku, sesungguhnya aku tidak pernah melihat guru yang terbaik cara pengajarannya sebelum dan selepasnya Rasulullah SAW. Maka demi Allah, Baginda Rasulullah SAW tidak pernah memarahiku, memukulku dan mencelaku. ${ }^{15}$ Sungguh pola pendidikan yang visioner yang telah diterapkan 1400 tahun yang lalu sebelum teori tentang otak ditemukan, dan pada usia ini sepatutnya orang tua dapat mengenalkan tekhnik bermuamalah atau berinteraksi yang baik atau sesuai zamannya, seperti ungkapan Ali bin Abi thalib : "Didiklah anakmu sesuai dengan zamannya, karena mereka hidup bukan di zamanmu”.

b. Fase 7 Tahun Kedua ( 8 tahun - 14 Tahun) pada masa usia ini aspek penguatan terhadap beberapa aspek perkembangan pada anak diantaranya aspek moral agama, afeksi, kognitif, bahasa dan psikomotorik sangat penting untuk distimulasi, terutama pembekalan aqidah anak untuk memematangkan kecerdasan spiritual anak juga ditekankan ketika anak mulai memasuki usia 7 Tahun. Dalam hadits tentang pendidikan shalat terhadap anak usia tujuh tahun, dijelaskan:

" Dari 'Amar bin Syu'aib, dari ayahnya dari kakeknya ra., ia berkata: Rasulullah saw. Bersabda: "perintahlah anak-anakmu mengerjakan salat ketika berusia tujuh tahun, dan pukullah mereka karena meninggalkan salat bila berumur sepuluh tahun, dan pisahlah tempat tidur mereka (laki-laki dan perempuan)!'. (HR. Ahmad dan Abu Daud dalam kitab sholat) ${ }^{16}$

Demikian pula halnya dengan kognitif , bahasa dan psikomotor seperti tertuang dalam Hadits Abi Rafi' tentang 4 aspek pendidikan

14 Wismiarti, op. cit H.19

15 Ida. S widyawati, op.cit 43

16 Ida. S widyawati, Sebuah Pekerjaan Bernama Ayah, PT. Arga Tilanta, Jakarta 2018.H.103 
AL-MUDARRIS:journal of education, Vol. 2. No. 2 Oktober 2019, ISSN: 2620-5831 (print), ISSN: 2620-4355(online)

DOI: $10.32478 /$ al-mudarris.v\%vi\%i.264

"Dari Abi Rafi' dia berkata: aku berkata: wahai Rasul Allah apakah ada kewajiban kita terhadap anak, seperti kewajiban mereka terhadap kita?, beliau menjawab: ya, kewajiban orang tua terhadap anak yaitu mengajarkan menulis, berenang, memanah, mewariskan dan tidak memberikan rizki kecuali yang baik".

Dengan demikian pada dasarnya stimulasi tentang perkembangan AUD dalam Islam memiliki periode yang cukup panjang, akan tetapi penulis hanya membatasi pada usia menuju balighh yaitu fase tujuh tahun kedua. Dan ternyata pendidikan anak usia dini dalam Islam telah teraplikasi sejak 1400 tahun yang lalu saat belum tercetuskannya teori otak (brain based learning).

\section{METODOLOGI PENELITIAN}

Penelitian ini menggunakan pendekatan penelitian studi kepustakaan (library research). Studi kepustakaan merupakan studi yang digunakan dalam mengumpulkan informasi dan data dengan bantuan berbagai macam material yang ada di perpustakaan seperti dokumen, buku, majalah, kisah-kisah sejarah, dsb.

Studi kepustakaan juga dapat mempelajari berbagai buku referensi serta hasil penelitian sebelumnya yang sejenis yang berguna untuk mendapatkan landasan teori mengenai masalah yang akan diteliti. Studi kepustakaan juga berarti teknik pengumpulan data dengan melakukan penelaahan terhadap buku, literatur, catatan, serta berbagai laporan yang berkaitan dengan masalah yang ingin dipecahkan. Penyusunan laporan sumber data yang menjadi bahan akan penelitian ini berupa buku, jurnal dan situs internet yang terkait dengan topik yang telah dipilih. Sumber data penelitian ini terdiri dari Al-Quran, buku, artikel dan jurnal tentang pengasuhan dan pendidikan anak usia dini.

Teknik pengumpulan data dalam penelitian ini adalah dokumentasi, yaitu mencari data mengenai hal-hal atau variabel yang berupa catatan, buku, makalah atau artikel, jurnal dan sebagainya. Teknik Analisis Data yang digunakan dalam penelitian ini adalah metode analisis isi (Content Analysis). Analisis ini digunakan untuk mendapatkan inferensi yang valid dan dapat diteliti ulang berdasarkan konteksnya.

\section{HASIL DAN PEMBAHASAN}


Pertama, Dalam Crain menjelaskan beragam perspektif tentang pendidikan anak usia dini dengan bingkai paradigma barat, yaitu penjelasan mengenai wacana yang berkembang pada abad pertengahan bahwa para pemikir beranggapan sosok anak usia dini /bayi atau anakanak sebagai makhluk yang telah terbentuk secara utuh, sebuah miniatur orang dewasa dan pandangan ini amat mendominasi seluruh abad pertengahan. Hal ini terlihat pada lukisan-lukisan abad pertengahan yang selalu menggambarkan anak-anak bahkan yang baru lahir dengan proporsi tubuh dan ciri-ciri wajah manusia dewasa. Karena menurut mereka anak-anak berbeda hanya dalam ukuran, seolah mereka sudah dibentuk sebelumnya (Preformed) dalam cetakan orang dewasa. Selain itu, pandangan ini terus dipegang selama berabad-abad, dari abad ke- 5 SM hingga abad ke 18 masih banyak ilmuwan yang memegang pandangan Performasionanisme.

Namun, pada abad 18 pun sudah ada beberapa pemikiran yang berkembang mengenai perkembangan anak usia dini, seperti Jhon Locke (1632-1704) yang Dalam persfektifnya sepatutnya anak-anak banyak latihan fisik, sehingga tubuh mereka menjadi kuat, bahkan dia menyarankan agar anak-anak bermain di luar rumah apa pun musimnya sehingga mereka bisa belajar untuk bertahan dari kerasnya segala macam cuaca. Selain itu tentang kediplinan, menurutnya harus tegas dari awal karena kebiasaan awal akan sulit diubah. Karena seorang anak diibaratkan seperti kertas kosong (tabularasa) yang masih suci dan terjaga fitrahnya. Selain itu ada Filsafat pendidikan Rousseau (17121778), dalam perspektif Rousseau anak-anak bukan wadah kosong atau kertas kosong melainkan sudah memiliki mode perasaan dan pemikirannya sendiri. Dan Ia pun menjelaskan tahapan perkembangan anak, yaitu: Dengan tahapan-tahapan, tahap I (0-2 tahun) Bayi mengalami dunia langsung lewat inderannya. Tahap II (2-12 tahun) tahap dimulai ketika anak memiliki sebuah indepensi baru dengan bisa berjalan, makan, berbicara, dll. Tahap III (12-15 tahun) masa transisi kanak-kanak dan dewasa.

Tahap IV masa dewasa, anak-anak menjadi makhluk yang sepenuhnya sosial hanya di tahap keempat, dimulai dari masa pubertas dan Rousseau menyatakan bahwa pubertas dimulai dari usia 15 tahun. Di titik ini seorang mulai tertarik dengan orang lain lawan jenis. Selanjutnya,Teori Pendewasaan Arnold Gessel (1880-1961) Konsep Kematangan menurut Gessel dalam perkembangan anak adalah produk 
AL-MUDARRIS:journal of education, Vol. 2. No. 2 Oktober 2019,

ISSN: 2620-5831 (print), ISSN: 2620-4355(online)

DOI: $10.32478 /$ al-mudarris.v\%vi\%i.264

dari lingkungannya yang berasal dari dalam yaitu aksi dari gen-gen tubuhnya Gessel menyebutnya ini sebagai proses kematangan. Dan dalam proses pematangan anak sepatutnya: Orang tua tidak semestinya memaksa anak memasuki pola-pola tindakan yang tidak mereka pahami, melainkan mengikuti petunjuk dari anak-anak itu sendiri. Kemudian Filsafat Pendidikan Montessory (1870 -1952) Maria Montessori berpendapat bagian terpenting dari kehidupan bukanlah di universitas, tetapi periode pertama dari usia 0-6 tahun, karena selama periode ini seluruh instrument besar manusia terbentuk, bukan hanya kecerdasan tetapi seluruh kecakapan psikis.

Dari analisis teori PAUD barat memiliki kesinambungan teori, hal ini terlihat dari pengembangan dan penelitian tentang perkembangan anak hingga abad 20 saat ini, seperti perkembangan kognitif Jean Piaget, zona perkembangan (Zone Proximal Development/ZPD) Vygotsky, teori hubungan sosial Sara Smilanski, perkembangan sosial emosional Eric Ericson dan Anne Freud, serta yang sering menjadi perbincangan di abad 20 ini yaitu teori Howard Gardner tentang kecerdasan jamak (multiple intelligence) dll. Sehingga perkembangan tentang anak dalam perspektif barat lebih sering menjadi acuan oleh para pendidik dan di dalam dunia pendidikan.

Kedua, Pendidikan anak usia dini secara Islam berdasarkan dari hasil analisis terhadap sejumlah ayat Al-Qur'an dan keterangan hadits yang relevan serta buku keislaman ditemukan bahwa perkembangan anak rentang dari lahir hingga usia pubertas yang ditandai dengan ihtilam. Dalam tradisi hukum Islam disebut aqil baligh. Dan pondasi pendidikan anak usia dini dalam Islam memiliki 3 fase dalam usia per 7 tahun. Tujuh tahun pertama perkembangan anak pada rentang perkembangan usia 0-7 tahun itu, anak ada pada fase ahliyatul wujub. Anak laksana raja yang berhak mendapatkan layanan pendidikan secara prima, seperti diriwayatkan oleh Muslim bahwa Al-Sulami telah berkata, "maka demi bapak dan ibuku, sesungguhnya aku tidak pernah melihat guru yang terbaik cara pengajarannya sebelum dan selepasnya Rasulullah SAW. Maka demi Allah, Baginda Rasulullah SAW tidak pernah memarahiku, memukulku dan mencelaku. (H.R. Muslim).

Akhir capaian pendidikan anak usia dini adalah menjadi individu mandiri, menjadi mumayyiz (7-14 tahun) yang memiliki kompetensi dasar untuk menjalankan taklif Allah, berupa peribadatan dan ketentuan norma syariat; Seperti dalam hadits tentang pendidikan shalat terhadap anak usia tujuh tahun, dijelaskan: "Dari 'Amar bin 
Syu'aib, dari ayahnya dari kakeknya ra., ia berkata: Rasulullah saw. Bersabda: "perintahlah anak-anakmu mengerjakan salat ketika berusia tujuh tahun, dan pukullah mereka karena meninggalkan salat bila berumur sepuluh tahun, dan pisahlah tempat tidur mereka (laki-laki dan perempuan)!”. (HR. Ahmad dan Abu Daud dalam kitab sholat).

Selain itu, mampu menolong diri sendiri dan orang lain, berani mengambil keputusan dan sanggup memecahkan masalah secara bijaksana, serta bangga menghasilkan karya baru. Seperti hadits berikut ini: "Dari Abi Rafi' dia berkata: aku berkata: wahai Rasul Allah apakah ada kewajiban kita terhadap anak, seperti kewajiban mereka terhadap kita?, beliau menjawab: ya, kewajiban orang tua terhadap anak yaitu mengajarkan menulis, berenang, memanah, mewariskan dan tidak memberikan rizki kecuali yang baik".

Kompetensi ini ditanamkan kepada anak melalui proses tarbiyah yang menekankan pada tindakan membimbing anak menjadi berdaya dengan berbagai keterampilan hidup. Di sisi lain, proses pembudayaan nilai-nilai dilakukan melalui proses ta'dib yang menekankan pada penanaman sikap disiplin dan budaya tertib.

Ketiga, Komparasi dari 2 perspektif PAUD baik dari teori barat dan Islam. Dalam konsep teori PAUD Islam telah ada lebih awal dari teori barat, yaitu 1400 tahun yang lalu sejak Al-Qur'an diturunkan. Karena dalam Islam rujukan utama adalah Al-Qur'an dan As-Sunnah, dengan demikian pendidikan anak usia dini dalam Islam telah ada sejak zaman Nabi. Hal tersebut terlihat dari metode pengajaran Rasulullah SAW. yang telah memiliki pendekatan berdasarkan teori otak (brain based learning) yaitu tanpa marah, memukul dan mencela.

Perbedaan kedua, yaitu : teori PAUD dalam konteks teori barat dikaji melalui 2 fase, yaitu tetika anak dalam kandungan dan usia anak tumbuh kembang hingga dewasa. Sedangkan Pendidikan usia dini dalam islam terbagi menjadi 3 fase, yaitu fase memilih jodoh/pasangan, fase pra-natal (dalam kandungan), dan fase pasca-natal (fase pra baligh dan baligh).

Dengan demikian dalam teori-teori barat yang berkembang, AUD disoroti tahap perkembangannya saat bayi mulai tumbuh dalam rahim ibunya, sedangkan pola pendidikan anak usia dini menurut persfektif Islam atau dalam tinjauan Al-Qur'an dan Sunnah dimulai sejak saat memilih pasangan hidup. Pendidikan anak usia dini yang menjadi diskursus pendidik saat ini lebih sering mengadopsi teori barat. 
Karena memang kurang menjadi sorotan dan belum familiar di kalangan pendidik, khususnya pendidik muslim. Padahal secara implicit teori-teori Islam lebih awal mencetuskan tentang PAUD dan ada beberapa teori barat yang menyerupai teori PAUD Islam seperti teori Jhon Locke dengan kandungan hadits nabi SAW mengenai fithrah anak (tabularasa) dan mengedepankan pembelajaran motorik sejak dini untuk anak.

Namun tidak dipungkiri penelitian dan kodifikasi tulisan dalam PAUD Islam tidak berkesinambungan hingga saat ini, berbeda halnya dengan teori barat yang terus berkembang hingga saat ini seperti perkembangan kognitif Jean Piaget, zona perkembangan (Zone Proximal Development/ ZPD) Vygotsky, teori hubungan sosial Sara Smilanski, perkembangan sosial emosional Eric Ericson dan Anne Freud, serta yang sering menjadi perbincangan di abad 20 ini yaitu teori Howard Gardner tentang kecerdasan jamak (multiple intelligence) dll. Sehingga perkembangan tentang anak dalam perspektif barat lebih sering menjadi acuan oleh para pendidik dan di dalam dunia pendidikan.

Sehingga sangat disayangkan teori PAUD dalam perpektif Islam sejak 1400 tahun yang lalu telah memiliki pijakan tentang metode brain based learning dengan mengambil figur Rasulullah sebagai guru sempurna seperti hadits diatas, kurang memiliki pamor daripada teori barat. Dan hal ini pula yang menjadi nilai lebih dari PAUD Islam yaitu guru dan pendidik (baca; rasul dan shahabat) yang mencetuskan ide atau teori sudah menerapkan dalam penerapan pendidikan dan kehidupannya sendiri, berbeda dengan beberapa teori barat yang belum menerapkannya dalam kehidupannya, seperti Roussau yang teorinya diambil dari anak khayalannya bernama Emille akan tetapi ke 5 anaknya dimasukan ke dalam panti asuhan Negara.

\section{E. KESIMPULAN}

Berdasarkan hasil analisis data dan pembahasan, dapat diambil kesimpulan bahwa teori PAUD memiliki sejarah yang panjang baik dari sisi teori barat ataupun teori Islam. Dari kedua teori memiliki benang merah yang sama yaitu membentuk AUD yang memiliki kecakapan hidup. Teori PAUD Islam lebih awal dan menjadi pioneer dalam konsep PAUD namun teori tidak berkesinambungan hingga saat ini (tidak ada teori baru dengan kajian teori PAUD berdasarkan Al-Quran dan hadits yang telah ada). Meskipun teori barat ada diantaranya yang 
mirip dan seperti mengadopsi hadist nabi seperti teori Jhon Locke namum teori barat memiliki teori yang berkesinambungan hingga saat ini.

Dengan demikian apapun bentuk bentuk pendidikan AUD baik barat atau Islam yang terpenting menjadi uswatun Hasanah bagi AUD, seperti menurut Ki Hajar Dewantara memberikan pendidikan pada anak usia dini memiliki beberapa pendekatan yang diberi istilah sistem Among, yaitu: ${ }^{17}$ Ing ngarso sung tulodo, artinya: pendidik memberikan teladan di hadapan muridnya. Ing madya mangun karso, artinya pendidik menjadi stimulator sehingga anak mempunyai kesempatan mencoba dan berbuat sendiri. Tut Wuri Handayani, jika pendidik dibelakang wajib memberi dorongan, dan memantau daya agar anak bekerja sendiri.

\section{F. DAFTAR PUSTAKA}

Crain, William, Penerj. Yudi Santoso Teori Perkembangan Konsep dan Aplikasi, Penerbit Pustaka Pelajar, Yogyakarta ; 2007

Departemen Agama, Al-Qur'an Al-kariim https://www.kompasiana.com/elokkhusna/584a2e7e8d7a61d308d3824e /mendidik-anak-ala-ali-bin-abi-thalib-r-a, diunduh 11 Maret 2019

https://m.republika.co.id/berita/dunia-islam/fatwa/15/06/08/nplphtanjuran-alquran-bagi-muslimah-yang-menyusui https://tafsirweb.com/9581-surat-al-ahqaf-ayat-15.html https://ejournal.unisba.ac.id/index.php/tadib/article/view/3195

(Fadlullah, vol. 6 No.2, 2017 diakses tanggal 23 maret 2019 https://jurnaledukasikemenag.org/index.php/edukasi/article/view/138/9

3, Mastiyah, vol.5 No.3 juli-September 2017 diakses tanggal 23 maret 2019

Ibrahim, Ahmad Syawqi, Ensiklopedia mukjizat Ilmiyah Hadits Nabi Manusia dan Proses Penciptaannya, Sygma creative media, 2014 Krippendoff, Klaus. 1993. Analisis Isi: Pengantar Teori dan Metodologi. Jakarta: Citra Niaga Rajawali Press.

Masardi, Yudistira dan Sisca Y., Pendidikan Karakter Dengan Metode Sentra, Penerbit: Media Pustaka Sentra, Bekasi :2012,

\footnotetext{
${ }^{17}$ Soegeng Santoso , Pendidikan Anak Usia Dini Di Masa Mendatang,(
} Pidato pengukuhan guru besar Tetap Fakultas Ilmu Pendidikan, 2000), h. 28 
AL-MUDARRIS:journal of education, Vol. 2. No. 2 Oktober 2019, ISSN: 2620-5831 (print), ISSN: 2620-4355(online)

DOI: $10.32478 /$ al-mudarris.v\%vi\%i.264

Santoso, Soegeng, Pendidikan Anak Usia Dini Di Masa Mendatang,(Pidato pengukuhan guru besar Tetap Fakultas Ilmu Pendidikan, 2000).

Prastowo, Andi 2012. Metode Penelitian Kualitatif dalam Prespektif Rancangan Penelitian. Yogyakarta: Ar-Ruzz Media.

Widyawati ,Ida. S, Anak dari surga menju surga, PT. Arga Tilanta, Jakarta 2018

Widyawati ,Ida. S, Sebuah Pekerjaan Bernama Ayah, PT. Arga Tilanta, Jakarta 2018

Wismiarti, Mengapa Surga Di Telapak Kaki Ibu, Penerbit : ESQ 165, Jakarta : 2013.

Yahya , Harun, Ensiklopedia Mukjizat Ilmiyah Al-Quran Keajaiban Penciptaan, Sygma Creative Media, 2014 